\title{
PREDIKSI PENJUALAN KAYU LAPIS DI CV DIATO WOOD SEJAHTERA DENGAN METODE TREND MOMENT BERBASIS WEB
}

\author{
Jemmy Andriano Frans, Mira Orisa, Suryo Adi Wibowo \\ Program Studi Teknik Informatika S1, Fakultas Teknologi Industri \\ Institut Teknologi Nasional Malang, Jalan Raya Karanglo km 2 Malang, Indonesia \\ Jemmyfrans40@gmail.com
}

\begin{abstract}
ABSTRAK
Salah satu tujuan dari perusahaan adalah mencari keuntungan atau laba yang semaksimal mungkin, untuk dapat mencapai tujuan tersebut. Perusahaan harus dapat mengikuti perkembangan dunia perindustrian baik dalam bidang teknologi informasi maupun dalam bidang manajemen. Seiring dengan perkembangan ilmu dan teknologi, pemanfaatan komputer di segala bidang sudah merupakan suatu keharusan. Computer Based Information Sistem (Sistem Informasi Berbasis Komputer) yang salah satunya adalah Sistem Pendukung Keputusan (Decision Support Sistem) adalah suatu sistem informasi komputer yang interaktif dan dapat memberikan alternatif solusi bagi pembuat keputusan.

Metode Trend Moment merupakan metode yang digunakan dalam melakukan Forecast atau prediksi penjualan, yang nantinya akan dijadikan sebagai dasar peningkatan penjualan pada periode berikutnya. Metode Trend Moment menggunakan cara-cara perhitungan statistika dan matematika tertentu untuk mengetahui fungsi garis lurus sebagai pengganti garis putus-putus yang dibentuk oleh data historis perusahaan.

Hasil pengujian dari sistem yang telah di bangun yaitu Sistem Prediksi Penjualan Kayu Lapis di CV Diato Wood Sejahtera Berbasis Web ini menyatakan bahwa hasil dari program yang telah dibuat sudah berjalan dengan baik, itu di buktikan dengan hasil pengujian fungsional sistem dan pengujian pengguna dengan akses sebagai admin, user sesui dengan fungsinya pada browser. Pada tahap pengujian aplikasi dengan menggunakan 3 browser yaitu Mozilla Firefox, Google Chrome dan Microsoft Edge .Semua fungsi dari sistem berjalan sesui dengan yang di inginkan .
\end{abstract}

Kata Kunci : Metode Trend Moment, Prediksi penjualan

\section{PENDAHULUAN}

Salah satu tujuan dari perusahaan adalah mencari keuntungan atau laba yang semaksimal mungkin, untuk dapat mencapai tujuan tersebut. Perusahaan harus dapat mengikuti perkembangan dunia perindustrian baik dalam bidang teknologi informasi maupun dalam bidang manajemen.

$\mathrm{Cv}$ Diato Wood Sejahtera merupakan sebuah pabrik, yang bergerak dalam memproduksi kayu lapis yang beralamat di Jl. Yos Sudarso No.18B, Setran,Bedali, Kec. Lawang,Malang, Jawa Timur. Salah satu aspek strategis pabrik agar dapat bersaing dalam dunia bisnis yaitu perencanaan dan tersedianya barang-barang untuk memenuhi tuntutan pasar. Oleh karena itu peran pabrik untuk memahami dan mempunyai kemampuan dalam meramalkan keadaan bisnis di masa depan sangat dibutuhkan. Tentunya dengan kerangka fikir yang sistematis, rasional dan ekonomis merupakan faktor-faktor yang diperlukan dalam proses perencanaan dan pengambilan keputusan.

Metode prediksi adalah sebuah metode yang mampu melakukan analisa terhadap faktor atau beberapa faktor yang diketahui mempengaruhi terjadinya sebuah peristiwa dengan terdapat waktu tenggang yang panjang antara kebutuhan akan pengetahuan terjadinya sebuah peristiwa di waktu mendatang dengan waktu telah terjadinya peristiwa tersebut di masa lalu. Apabila metode prediksi ini diterapkan dalam bagian proses perencanaan produksi maka pihak perusahaan akan lebih terbantu dalam penjadwalan produksi, karena metode ini dapat memberikan output terbaik sehingga diharapkan resiko kesalahan yang disebabkan oleh kesalahan perencanaan dapat ditekan seminimal mungkin. Untuk itu diusulkan suatu sistem yang dapat menghasilkan alternatif-alternatif keputusan dalam meramalkan penjualan kayu lapis dengan menggunakan metode Trend Moment.

\section{TINJAUAN PUSTAKA}

\subsection{Penelitian Terdahulu}

Indiah hartami sandti dan arif rahmat saputra dengan penelitiannya yang berjudul prediksi jumlah permintaan telor ayam menggunakan metode trend moment, dalam penelitiannya penulis melakukan perhitungan data jumlah penjualan telur ayam menggunakan data 2 tahun sebelumnya untuk mendapatkan hasil prediksi jumlah permintaan telur ayam yang akan datang. Pengujian dilakukan dengan menguji hasil prediksi untuk bulan September tahun 2017 sampai dengan bulan Juli tahun 2018. Hasil dari pengujian yang dilakukan pada sistem prediksi jumlah permintaan telur ayam, memiliki tingkat keakuratan yang tinggi berdasarkan nilai rata-rata kemungkinan kesalahan sebesar 1,4\%. [1]

S Syarif dengan penelitiannya yang berjudul implementasi estimasi perolehan biji cengkeh menggunakan metode trend moment dan semi averega 
menjelaskan bahwa Tujuan dari penelitian ini yaitu untuk meramalkan hasil perolehan ditahun mendatang berdasarkan data perolehan 5 tahun sebelumnya di kabupaten Tolitoli kecamatan Ogodeide. Metode yang digunakan adalah trend moment dan semi average berbasis pemrograman PHP. Berdasarkan hasil analisis perhitungan yang sudah dilakukan, jika kedua metode digabungkan maka akan mengahasilkan prediksi yang lebih valid ini terlihat dari pengujian validitas dan membandingkan hasil perhitungan perolehan tahun 2016 dan hasil estimasi tahun 2016 dengan persamaan tersebut, dimana nilai perolehan tahun 2016 adala 10276 dan nilai estimasi tahun 2016 adalah 10171 ada selisih sekitar jadi dapat disimpulkan bahwa persentasi keakuratan adalah 98,98\%.[2]

Nurul Fuad dan Eko Sulistiono pada tahun 2016 membuat suatu aplikasi yang berjudul prediksi penjualan kerudung Rabbani di griya muslim store dukun gresik dengan metode trend moment, tujuan pembuatan aplikasi ini adalah untuk membantu store dukun gresik dalam mengetahui penjualan kerudung rabbani di masa yang akan datang dan mencegah kerugian penjualan di masa yang akan datang [3]

Pungky Andrean, Program penerapan metode KNN untuk hasil pertanian di kabupaten malang, Pada penelitiannya penulis mengimplementasikan prediksi hasil pertanian dengan metode K-NN. Hasil dari skripsi ini adalah sistem yang nantinya dapat membantu pemerintah Kabupaten Malang dalam meningkatkkan ketahanan di Kabupaten Malang. Dengan menggunakan sistem yang memiliki akurasi 73,91\% dan nilai error sebesar 26,08 maka pihak pemerintah dapat memfokuskan bantuan pertanian di daerah manayang perlu ditingkatkan kulitas dan kuantitas panennya dan pemasok dapat mencari daerah baru untuk memasok barang. Dengan demikian masyarakat luas dapat menikmati kebutuhan pokok dengan harga yang lebih terjangkau karena stok selalu terjaga.[4]

Moch Yuda Pratama, pada tahun 2016, Membuat sebuah penelitian yang berjudul penerapan metode trend moment untuk memprediksi kebutuhan obat di puskesmas desa blabak kecamatan kandat, dalam penelitian ini penulis membahas tentang penerapan metode trend moment untuk memprediksi kebutuhan obat di puskesmas desa blabak sebagai upaya untuk mengembangkan cara prediksi perhitungan jumlah obat dimasa yang masa yang akan datang [5]

\subsection{Peramalan}

Peramalan (Forecasting) adalah meramalkan, memproyeksikan, atau mengadakan perkiraaan/ taksiran terhadap berbagai kemungkinan yang akan terjadi sebelum suatu rancana yang lebih pasti dapat dilakukan. Peramalan (forecasting) adalah seni dan ilmu untuk memperkirakan kejadian di masa depan. Hal ini dapat dilakukan dengan melibatkan pengambilan data historis dan memproyeksikannya ke masa mendatang dengan suatu bentuk model matematis. Hal ini bisa juga merupakan pediksi intuisi yang bersifat subjektif.
Perencanaan yang efektif baik untuk jangka panjang maupun pendek bergantung pada peramalan permintaan untuk produk perusahaan. Peramalan (Forecasting), merupakan kegiatan memprediksi nilai-nila sebuah variabel berdasarkan nilai yang diketahui dari variabel tersebut atau variabel yang berhubungan. Terdapat dua macam metode yaitu metode kualitatif dan metode kuantitatif. Metode kualitatif hanya menggunakan intuisi saja, tanpa menggunakan pendekatan matematis maupun statistik. Situasi, kondisi, dan pengalaman peramal sangat mempengaruhi hasil ramalan.

\subsection{Metode Trend Moment}

Dalam penerapan aplikasi trend moment di CV Diato Wood Sejahtera ini adalah menggunakan data penjualan dari Januari 2018 sampai dengan Desember 2019. dalam penerapan metode Trend moment dapat dilakukan dengan menggunakan data historis dari satu variabel, adapun rumus yang digunakan dalam perhitungan. (Sugiarto dan Dergibson, 2002)

$\mathrm{Y}=\mathrm{a}+\mathrm{bX}$

penyusunan dari metode ini menurut Sugiarto \&Dergibson (2002), adalah : Dimana :

$\mathrm{Y}=$ nilai trend atau variabel yang akan diramalkan

$\mathrm{a}=$ bilangan constant

$\mathrm{b}=$ slope atau koefisien garis trend

$\mathrm{X}=$ indeks waktu (dimulai dari $0,1,2,3, \ldots \mathrm{n}$ )

Untuk mencari nilai a dan $\mathrm{b}$ pada rumus diatas, digunakan dengan cara matematis dengan penyelesaiannya menggunakan metode subtitusi dan metode eliminasi. Adapun persamaanya menurut Sugiarto \& Dergibson (2002), yaitu :

$\Sigma \mathrm{y}=\mathrm{a} . \mathrm{n}+\mathrm{b} \Sigma \mathrm{x} \ldots \ldots \ldots \ldots \ldots . .(2)$
$\Sigma \mathrm{xy}=\mathrm{a} . \Sigma \mathrm{x}+\mathrm{b} \Sigma \mathrm{x} 2 \ldots \ldots \ldots .(3)$

Dimana :

$\Sigma y=$ jumlah dari data penjualan

$\Sigma \mathrm{x}=$ jumlah dari periode waktu

$\Sigma x y=$ jumlah dari data penjualan dikali dengan periode waktu

$\mathrm{N}=$ jumlah data Setelah nilai ramalan yang telah diperoleh dari hasil peramalan dengan menggunakan indeks musin.

Perhitungan indeks musim yaitu (Gaspersz dalam fiati, 2009) :

Indeks Musim = rata-rata permintaan bulan tertentu / rata-rata permintaan pertahun Untuk mendapatkan hasil ramalan akhir setelah dipengaruhi oleh indeks musim maka akan menggunakan perhitungan sebagai berikut (Fiati, 2009) :

$\mathrm{Y}^{*}=$ Indeks Musim x Y

Dimana :

$\mathrm{Y}^{*}=$ hail ramalan dengan menggunakan metode trend mometn yang telah dipengaruhi indeks musim.

$\mathrm{Y}=$ hasil ramalan dengan menggunakan metode trend Setelah itu mengidentifikasi kesalahan terkecil yang digunakan dalam metode trend moment ini dengan menggunakan MSE (Mean Square Error) dan MAD (Mean Absolute Deviation) 
Mean Squared Error (MSE) adalah metode lain untuk mengevaluasi metode peramalan. Masing-masing kesalahan atau sisa dikuadratkan. Kemudian dijumlahkan dan ditambahkan dengan jumlah observasi. Pendekatan ini mengatur kesalahan peramalan yang besar karena kesalahan-kesalahan itu dikuadratkan. Metode itu menghasilkan kesalahankesalahan sedang yang kemungkinan lebih baik untuk kesalahan kecil, tetapi kadang menghasilkan perbedaan yang besar. Rumus Mean Squared Error (MSE) adalah

$$
M S E=\frac{\sum e_{i}^{2}}{n}=\frac{\sum\left(X_{i}-F_{i}\right)^{2}}{n}
$$

MAD (Mean Absolute Deviation) adalah metode peramalan menggunakan jumlah dari kesalahankesalahan yang absolut. Mean Absolute Deviation (MAD) mengukur ketepatan ramalan dengan merata-rata kesalahan dugaan (nilai absolut masing-masing kesalahan). MAD berguna ketika mengukur kesalahan ramalan dalam unit yang sama sebagai deret asli. Nilai MAD dapat dihitung dengan menggunakan rumus sebegai berikut.

$$
\text { MAD }=\frac{\sum \text { (absolut dari forecast errors) }}{\mathrm{n}}
$$

\section{METODE PENELITIAN}

\subsection{Metode}

Dalam penelitian ini kamu menggunakan metode Trend Moment. Metode trend moment menggunakan caracara perhitungan statistika dan matematika tertentu untuk mengetahui fungsi garis lurus sebagai pengganti garis patah-patah yang dibentuk oleh data historis perusahaan. Dengan demikian pengaruh unsur-unsur subyektif dapat dihindark Prinsip-prinsip pengerjaan metode trend moment adalah sebagai berikut: a) Kegiatan usaha sudah berjalan minimal dua tahun, digunakan sebagai data penjualan tahun yang lalu. b) Metode ini tidak mensyaratkan jumlah data harus genap. c) Jumlah data tahun lalu baik tahun ganjil maupun genap tetap diurut dari $0,1,2,3, \ldots .$. dst pada kolom $\mathrm{x}$.

Rumus metode trend moment:

$$
\begin{aligned}
& \text { 1. } Y=a+b x \\
& \text { 2. } b=\frac{n\left(\sum x y\right)-\left(\sum x\right)\left(\sum y\right)}{n\left(\sum x^{2}\right)-\left(\sum x\right)^{2}} \\
& \text { 3. } a=\frac{\sum y-b\left(\sum x\right)}{N}
\end{aligned}
$$

\subsection{Flowchart Sistem}

Flowchart atau diagram alir adalah suatu bagan dengan simbol-simbol tertentu yang menggambarkan urutan proses secara mendetail dan hubungan antara suatu proses (instruksi) dengan proses lainnya dalam suatu program.. Berikut adalah Flowchart dari sistem yang akan dibangun, seperti yang ditunjukan pada gambar 1.

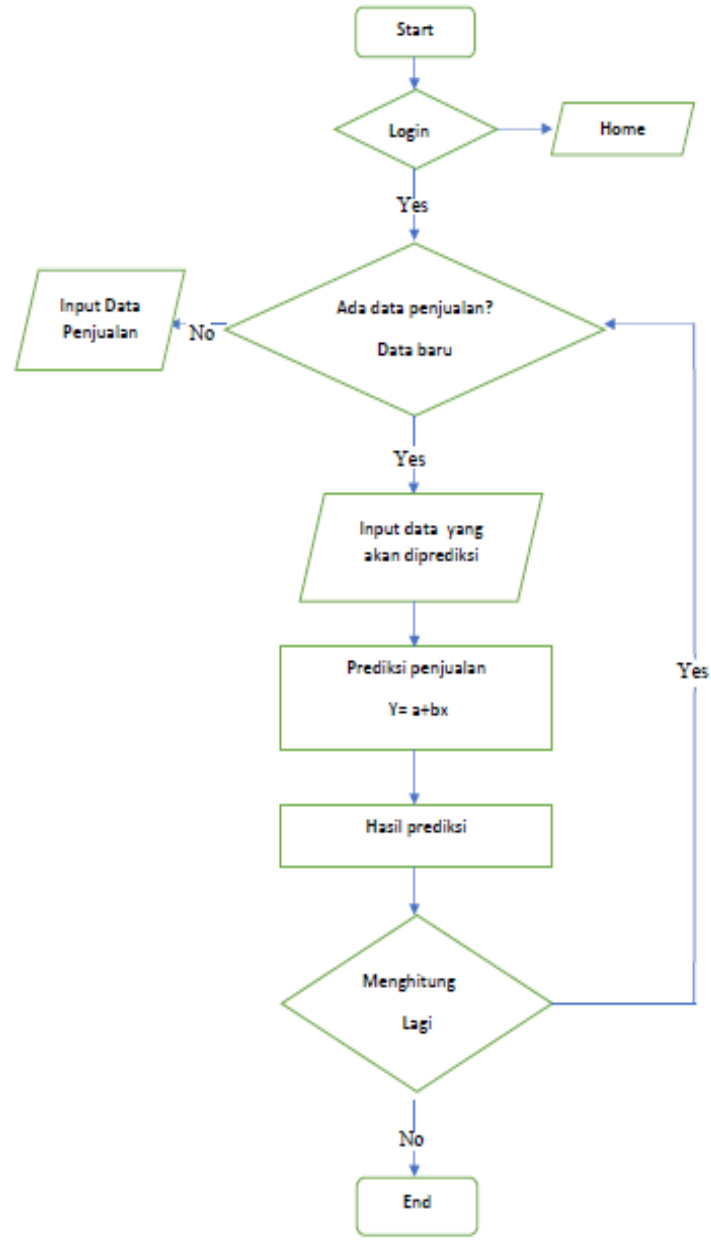

Gambar 1 Flowchart sistem

\subsection{Context Diagram}

Diagram konteks adalah diagram yang terdiri dari suatu proses dan menggambarkan ruang lingkup suatu sistem. Diagram konteks merupakan level tertinggi dari DFD yang menggambarkan seluruh input ke dalam sistem atau output dari sistem yang memberi gambaran tentang keseluruhan system seperti ditunjukkan pada Gambar 2.

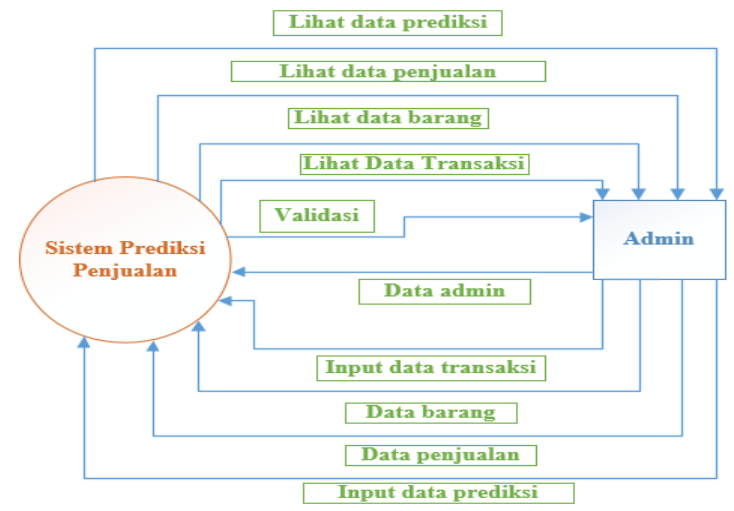

Gambar 2 Context diagram 


\subsection{Struktur Menu}

Struktur menu yang akan dirancang dalam pembuatan aplikasi ini adalah menu-menu yang terdapat dalam website ini. Dari sistem terdapat beberapa menu, diantaranya menu Data Admin, menu barang, menu penjualan, menu transaksi menu prediksi ,menu transaksi penjualan dan menu hitung prediksi, menu-menu tersebut bertujuan untuk mempermudah pembuat aplikasi dalam membuat interaksi pada aplikasi. Karena dengan struktur menu dapat digambarkan dengan jelas rancangan interaksi dari menu-menu dan sub-sub menu pada aplikasi yang dibuat. keseluruhan system seperti ditunjukkan pada Gambar 3.

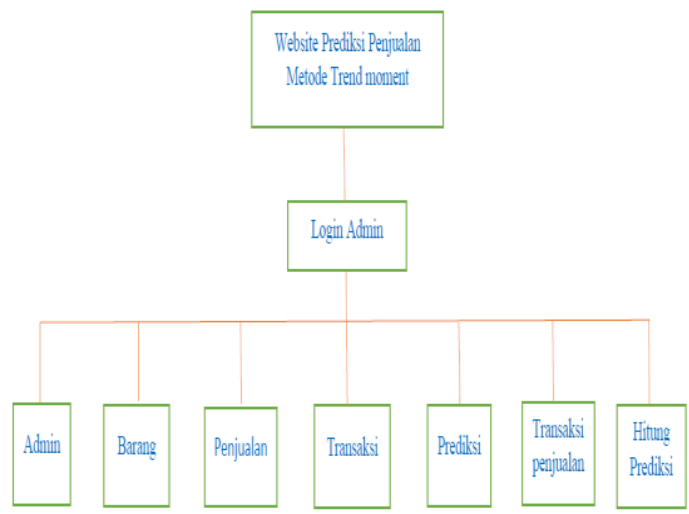

Gambar 3. Struktur Menu

\section{HASIL DAN PEMBAHASAN}

\subsection{Implementasi Sistem}

Implementasi sistem adalah prosedur yang dilakukan untuk menyelesaikan desain yang ada dalam dokumen desain sistem yang disetujui dan menguji, menginstal, memulai, serta menggunakan sistem yang baru atau sistem yang diperbaiki. Berikut adalah struktur dari tabel - tabel yang di gunakan pada sistem yang di bangun:

\section{Tabel Data admin}

$\begin{array}{lllll} & \text { \# } & \text { Nama } & \text { Jenis } & \text { Penyortiran } \\ \square & 1 & \text { id_admin } & \operatorname{int}(5) & \\ \square & 2 & \text { nama } & \operatorname{varchar}(50) & \text { latin1_swedish_ci } \\ \square & 3 & \text { username } & \operatorname{varchar}(50) & \text { latin1_swedish_ci } \\ \square & 4 & \text { password } & \operatorname{varchar}(50) & \text { latin1_swedish_ci } \\ \square & 5 & \text { level } & \operatorname{varchar}(50) & \text { latin1_swedish_ci }\end{array}$

Gambar 4. Tabel data Admin

\section{Tabel Data Barang}

$\begin{array}{lllll}\text { \# } & \text { Nama } & \text { Jenis } & \text { Penyortiran } \\ \square & 1 & \text { id_barang } & \text { int(5) } & \\ \square & 2 & \text { nama_barang } & \operatorname{varchar}(50) & \text { latin1_swedish_ci } \\ \square & 3 & \text { ukuran } & \operatorname{varchar}(50) & \text { latin1_swedish_ci } \\ \square & 4 & \text { harga } & \operatorname{varchar}(50) & \text { latin1_swedish_ci }\end{array}$

Gambar 5. Tabel Data Barang

\section{Tabel Data Penjualan}

$\begin{array}{lllll}\text { \# } & \text { Nama } & \text { Jenis } & \text { Penyortiran } \\ \square & 1 & \text { id_jual } & \text { int(10) } & \\ \square & 2 & \text { nama_barang } & \operatorname{varchar}(50) & \text { latin1_swedish_ci } \\ \square & 3 & \text { ukuran } & \operatorname{varchar}(50) & \text { latin1_swedish_ci } \\ \square & 4 & \text { bulan } & \text { varchar(50) latin1_swedish_ci } \\ \square & 5 & \text { tahun } & \text { varchar(50) latin1_swedish_ci } \\ \square & 6 & \text { penjualan } & \operatorname{varchar}(50) \text { latin1_swedish_ci }\end{array}$

Gambar 6. Tabel Data Penjualan

\section{Tabel Data Prediksi}

$\begin{array}{lllll} & \text { \# } & \text { Nama } & \text { Jenis } & \text { Penyortiran } \\ \square & 1 & \text { id_prediksi } & \text { int(10) } & \\ \square & 2 & \text { nama_barang } & \operatorname{varchar}(50) & \text { latin1_swedish_ci } \\ \square & 3 & \text { ukuran } & \operatorname{varchar}(50) & \text { latin1_swedish_ci } \\ \square & 4 & \text { bulan } & \operatorname{varchar}(50) & \text { latin1_swedish_ci } \\ \square & 5 & \text { tahun } & \operatorname{varchar}(50) & \text { latin1_swedish_ci } \\ \square & 6 & \text { hasil_prediksi } & \operatorname{varchar}(50) & \text { latin1_swedish_ci } \\ \square & 7 & \text { indeks_musim } & \operatorname{varchar}(50) & \text { latin1_swedish_ci } \\ \square & 8 & \text { mse } & \operatorname{varchar}(50) & \text { latin1_swedish_ci } \\ \square & 9 & \text { mad } & \operatorname{varchar}(50) & \text { latin1_swedish_ci }\end{array}$

Gambar 7. Tabel Data Prediksi

\section{Tabel Data Transaksi}

$\begin{array}{lllll}\text { \# } & \text { Nama } & \text { Jenis } & \text { Penyortiran } \\ \square & 1 & \text { id_transaksi } & \text { int(10) } & \\ \square & 2 & \text { tanggal } & \operatorname{varchar}(50) & \text { latin1_swedish_ci } \\ \square & 3 & \text { nama_barang } & \text { varchar(50) latin1_swedish_ci } \\ \square \quad 4 & \text { ukuran } & \text { varchar(50) latin1_swedish_ci } \\ \square \quad 5 & \text { harga } & \text { varchar(50) latin1_swedish_ci } \\ \square & 6 & \text { banyak_jual } & \text { int(11) } \\ \square \quad 7 & \text { total } & \operatorname{varchar}(50) & \text { latin1_swedish_ci } \\ \square \quad 8 & \text { bayar } & \text { int(11) } \\ \square & 9 & \text { kembali } & \text { int(11) }\end{array}$

Gambar 8. Tabel Data Transaksi

\subsection{Pengujian Aplikasi}

\section{Halaman Login Admin}

Halaman login admin disediakan untuk administrator agar dapat mengakses halaman admin sehingga perlu melakukan Login terlebih dahulu. Halaman admin, digunakan untuk mengakses halaman website yang terdapat pada website Trend Moment CV Diato Wood Sejahtera, Adapaun implementasi halaman login admin ditunjukkan pada Gambar 9. 


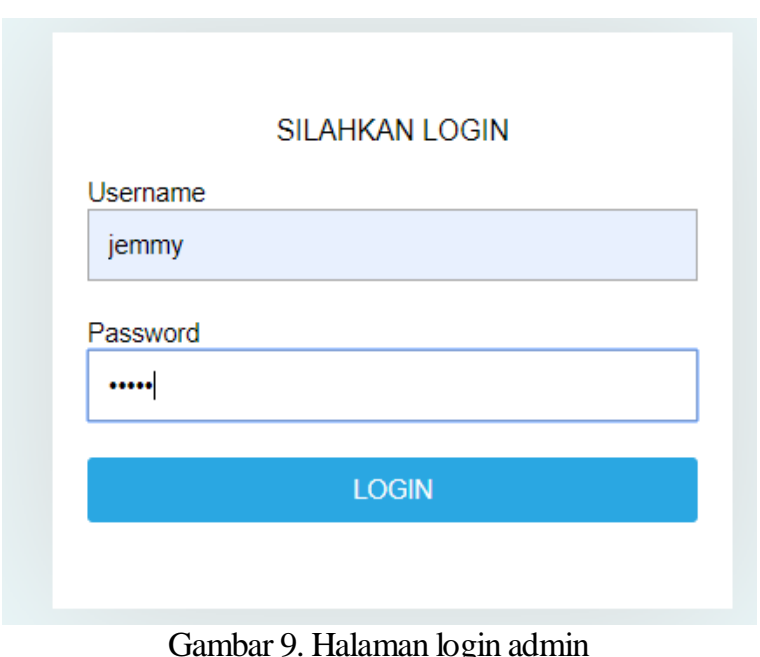

\section{Halaman Utama Website}

Halaman menu utama pada website yaitu halaman yang pertama kali akan di akses oleh Admin pada saat pertama kali mengakses website serta menampilkan menu-menu yang terdapat pada website serta data-data yang telah di masukan pada halaman admin sebelumnya.

Adapaun implementasi halaman utama website ditunjukkan pada Gambar 10.

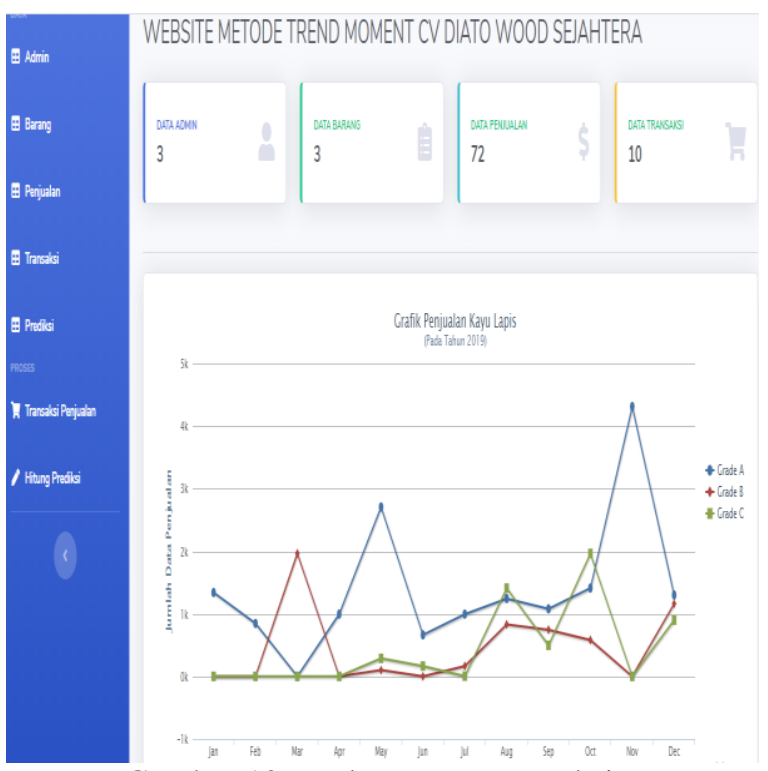

Gambar 10. Halaman utama website

\section{Tampilan Halaman Admin}

Halaman admin pada website ini adalah halaman yang berisi data dari nama admin, user name , beserta passwoard admin, kemudian di halaman admin juga berisi perintah edit, hapus, dan tambah data untuk mengubah data yang ada , menghapus, atau mau menambah data admin, Adapaun implementasi halaman admin ditunjukkan pada Gambar 11.

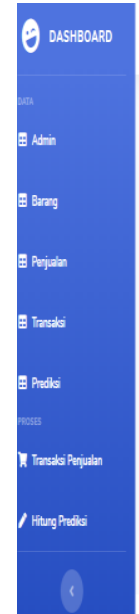

\section{Tampilan Halaman Barang}

Menu Barang pada website ini adalah menu yang berisi barang-barang yang diproduksi di pabrik CV Diato Wood Sejahtera, dan sudah dimasukan oleh admin. Adapaun implementasi halaman barang ditunjukkan pada Gambar 12.

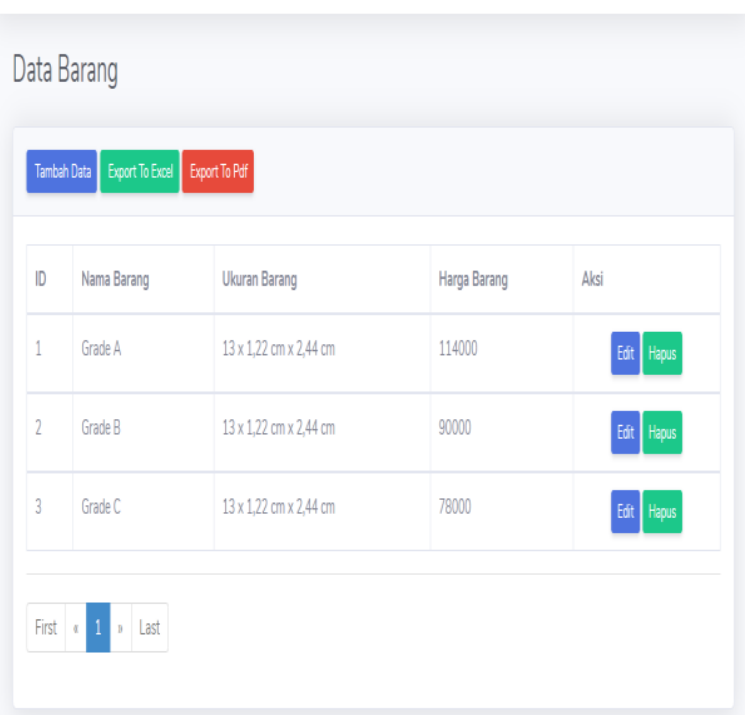

Gambar 12. Halaman Barang

\section{Tampilan Halaman Penjualan}

Halaman Penjualan pada website ini adalah menu yang berisi data data banyaknya penjualan barang perbulan yang sudah dimasuhkan oleh admin. Adapaun implementasi halaman barang ditunjukkan pada Gambar 13. 


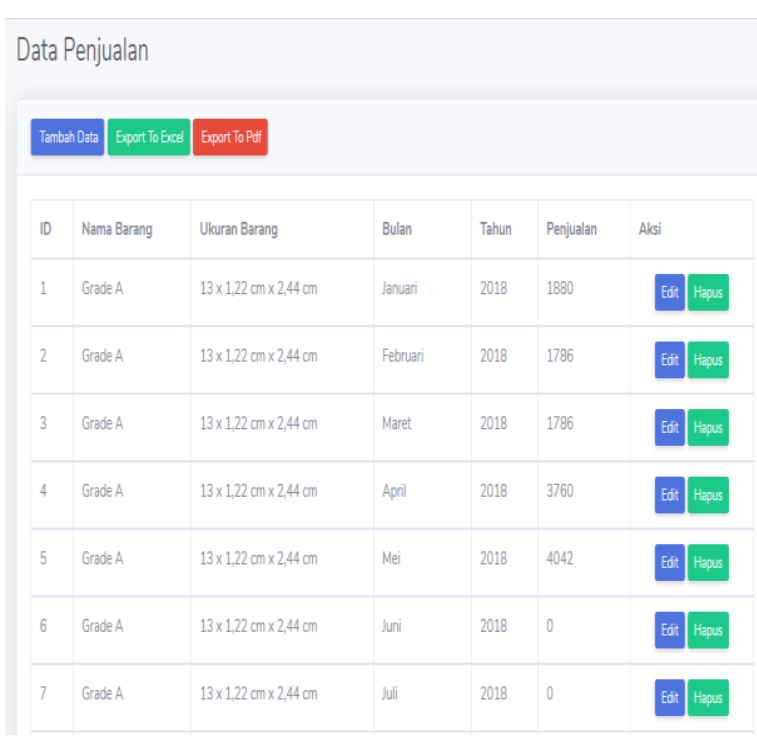

Gambar 13. Halaman Penjualan

\section{Tampilan Halaman Transaksi}

Halaman Transaksi pada website ini adalah menu yang menampilkan hasil dari transaksi penjualan, dimana halaman ini berisi nama barang dan jumlah pemjualan perbulannya. Adapaun implementasi halaman transaksi ditunjukkan pada Gambar 14.

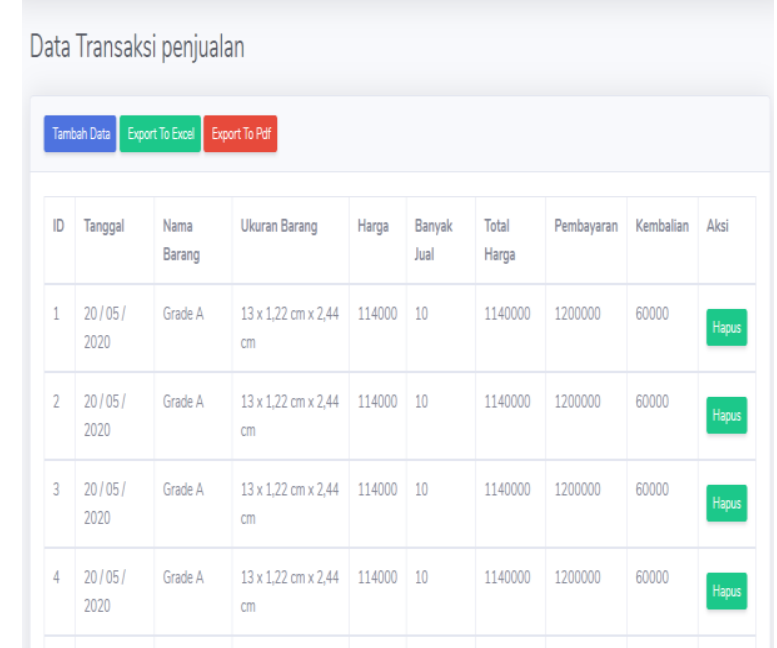

Gambar 14. Halaman transaksi penjualan

\section{Halaman Prediksi}

Halaman prediksi pada website ini adalah menu yang menampilkan hasil dari hitung prediksi yang ingin diketahui, dimana halaman ini berisi nama barang, prediksi penjualan bulan dan tahun yang akan datang, indeks musim, MSE dan MAD. Adapaun implementasi halaman prediksi ditunjukkan pada Gambar 15.

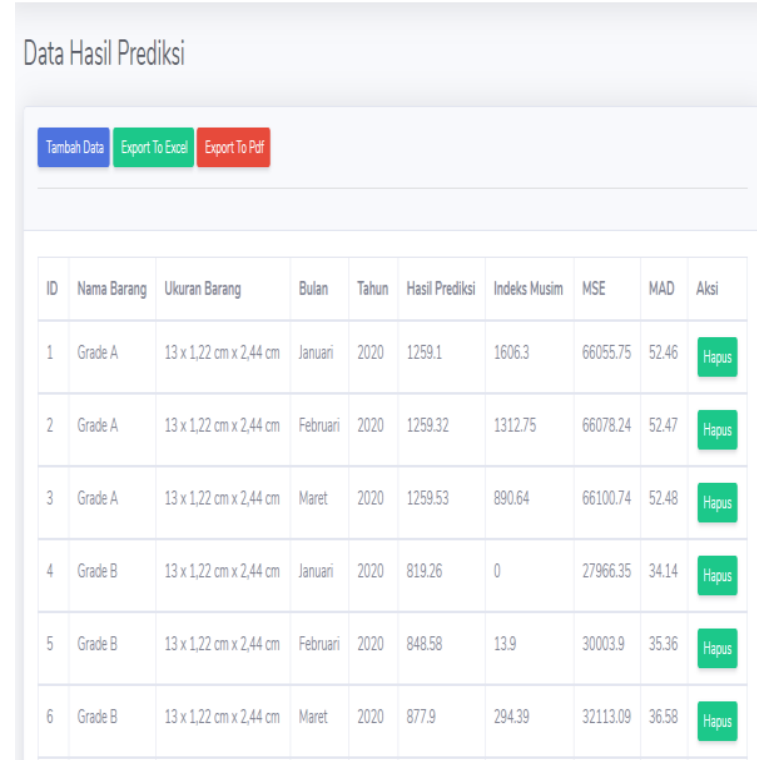

Gambar 15. Tampilan halaman prediksi

\section{Halaman Transaksi Penjualan}

Halaman Transaksi penjualan pada website ini adalah menu yang berisi proses pembelian dan pembayaran dan nantinya dicetak menjadi nota pembayaran dan diprint menjadi bukti pembayaran .Adapaun implementasi halaman transaksi penjualan ditunjukkan pada Gambar 16.

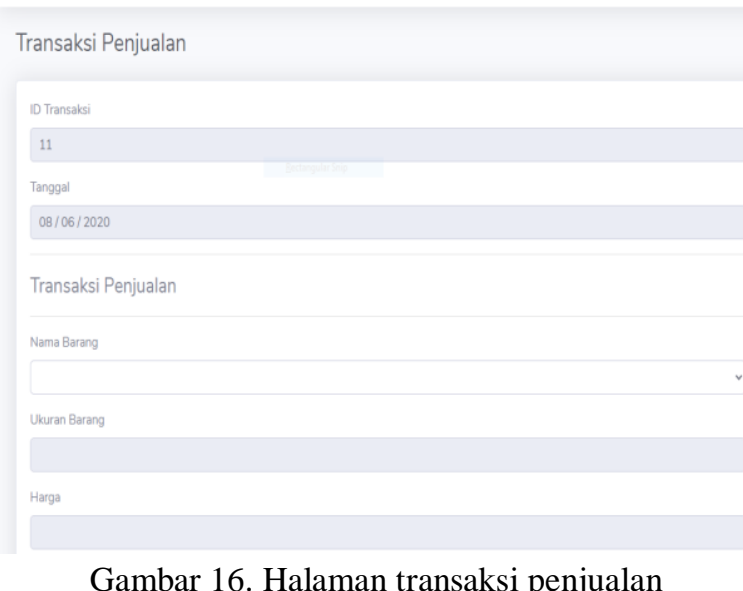

\section{Halaman Hitung Prediksi}

Halaman hitung prediksi pada website ini adalah menu yang berisi nama barang, ukuran barang, bulan dan tahun untuk memprediksi penjualan barang ditahun yang akan datang. Adapaun implementasi halaman hitung prediksi ditunjukkan pada Gambar 17. 


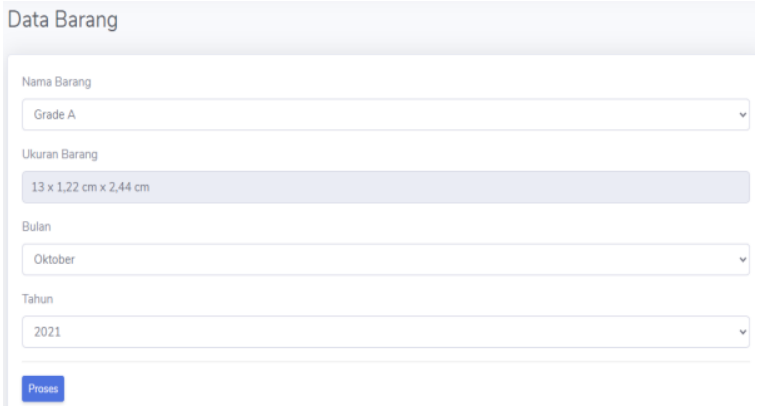

Gambar 17. Halaman hitung prediksi

\section{Tabel Hasil Pengujian Metode}

Pengujian metode dilakukan berdasarkan semua jenis barang untuk periode waktu ditentukan bulan Agustus sampai Oktober tahun 2019.

Tabel 1 . Hasil pengujian Metode

\begin{tabular}{|l|l|l|l|l|}
\hline \multicolumn{1}{|c|}{ Bulan } & \multicolumn{1}{c|}{ Barang } & $\begin{array}{c}\text { Data } \\
\text { asli }\end{array}$ & $\begin{array}{c}\text { Hasil } \\
\text { prediksi }\end{array}$ & Eror \\
\hline Agustus & Grade A & 1245 & 1257,83 & $1 \%$ \\
\hline September & Grade A & 1079 & 1258,03 & $1 \%$ \\
\hline Oktober & Grade A & 1411 & 1258,24 & $0,1 \%$ \\
\hline Agustus & Grade B & 830 & 643,43 & $0,2 \%$ \\
\hline September & Grade B & 747 & 672,66 & $0,1 \%$ \\
\hline Oktober & Grade B & 581 & 701,98 & $2 \%$ \\
\hline Agustus & Grade C & 1411 & 1004,22 & $0,2 \%$ \\
\hline September & Grade C & 498 & 1044,3 & $1,1 \%$ \\
\hline Oktober & Grade C & 1966 & 1084,38 & $0,4 \%$ \\
\hline
\end{tabular}

Dari pengujian diatas, diperoleh tingkat eror terendah adalah barang Grade B dipenjualan bulan september dan Grade A dipenjualan bulan oktober dengan eror $0,1 \%$,dan tingkat eror tertinggi adalah barang Grade B dipenjualan bulan oktober dengan eror $2 \%$

\section{Tabel Pengujian Fungsional}

Tabel 2. Hasil Pengujian Fungsional

\begin{tabular}{|c|l|c|c|c|}
\hline \multirow{2}{*}{ No } & \multicolumn{1}{|c|}{ Yang diuji } & \multicolumn{3}{|c|}{ Browser } \\
\cline { 3 - 5 } & & $\begin{array}{c}\text { Google } \\
\text { Chrome }\end{array}$ & $\begin{array}{c}\text { Mozilla } \\
\text { Firefox }\end{array}$ & $\begin{array}{c}\text { Microsoft } \\
\text { Edge }\end{array}$ \\
\hline 1 & Halaman login & $\sqrt{ }$ & $\sqrt{ }$ & $\sqrt{ }$ \\
\hline 2 & Halaman utama & $\sqrt{ }$ & $\sqrt{ }$ & $\sqrt{ }$ \\
\hline 3 & Halaman admin & $\sqrt{ }$ & $\sqrt{ }$ & $\sqrt{ }$ \\
\hline 4 & Halaman Barang & $\sqrt{ }$ & $\sqrt{ }$ & $\sqrt{ }$ \\
\hline 5 & Halaman Penjualan & $\sqrt{ }$ & $\sqrt{ }$ & $\sqrt{ }$ \\
\hline 6 & $\begin{array}{l}\text { Halaman Transaksi } \\
\text { Penjualan }\end{array}$ & $\sqrt{ }$ & $\sqrt{ }$ & $\sqrt{ }$ \\
\hline 7 & Halaman Prediksi & $\sqrt{ }$ & $\sqrt{ }$ & $\sqrt{ }$ \\
\hline 8 & $\begin{array}{l}\text { Halaman hitung } \\
\text { Prediksi }\end{array}$ & $\sqrt{ }$ & $\sqrt{ }$ & $\sqrt{ }$ \\
\hline 9 & $\begin{array}{l}\text { Tambah Data } \\
\text { Barang }\end{array}$ & $\sqrt{ }$ & $\sqrt{ }$ & $\sqrt{ }$ \\
\hline
\end{tabular}

\begin{tabular}{|c|l|c|c|c|}
\hline 10 & $\begin{array}{l}\text { Tambah Data } \\
\text { Penjualan }\end{array}$ & $\sqrt{ }$ & $\sqrt{ }$ & \multicolumn{2}{|c|}{} \\
\hline 11. & Edit Data Barang & $\sqrt{ }$ & $\sqrt{ }$ & $\sqrt{ }$ \\
\hline 12 & Hapus Data Barang & $\sqrt{ }$ & $\sqrt{ }$ & $\sqrt{ }$ \\
\hline 13 & Edit data Penjualan & $\sqrt{ }$ & $\sqrt{ }$ & $\sqrt{ }$ \\
\hline 14 & $\begin{array}{l}\text { Hapus Data } \\
\text { Penjualan }\end{array}$ & $\sqrt{ }$ & $\sqrt{ }$ & $\sqrt{ }$ \\
\hline 15 & $\begin{array}{l}\text { Nota Transaksi } \\
\text { Penjualan }\end{array}$ & $\sqrt{ }$ & $\sqrt{ }$ & $\sqrt{ }$ \\
\hline 16 & $\begin{array}{l}\text { Cetak Transaksi } \\
\text { Penjualan }\end{array}$ & $\sqrt{ }$ & $\sqrt{ }$ & $\sqrt{ }$ \\
\hline 17 & Laporan data barang & $\sqrt{ }$ & $\sqrt{ }$ & $\sqrt{ }$ \\
\hline 18 & $\begin{array}{l}\text { Laporan data } \\
\text { penjualan }\end{array}$ & $\sqrt{ }$ & $\sqrt{ }$ & $\sqrt{ }$ \\
\hline 19 & $\begin{array}{l}\text { Laporan Data } \\
\text { Transaksi }\end{array}$ & $\sqrt{ }$ & $\sqrt{ }$ & $\sqrt{ }$ \\
\hline 20 & $\begin{array}{l}\text { Laporan Data } \\
\text { Prediksi }\end{array}$ & $\sqrt{ }$ & $\sqrt{ }$ & $\sqrt{ }$ \\
\hline 21 & Logout & \multicolumn{1}{|c|}{} & & $\sqrt{ }$ \\
\hline
\end{tabular}

Keterangan :

$\sqrt{ }=$ Berjalan

$\mathrm{X}=$ Tidak Berjalan

Tabel 4.3. Pengujian Pengguna

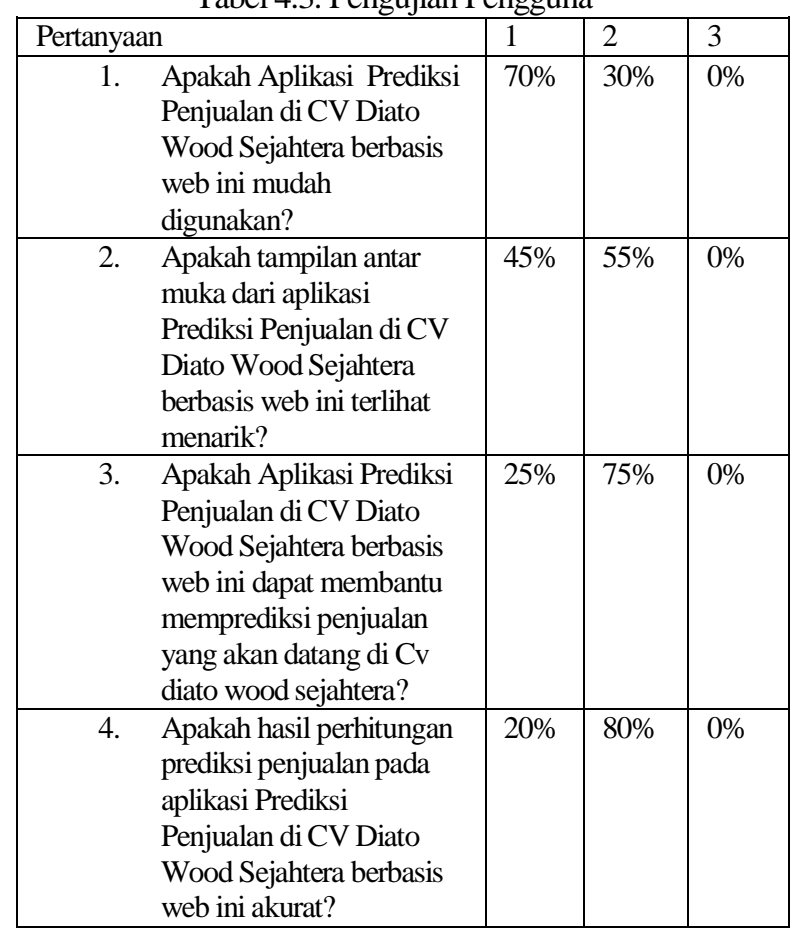

Keterangan :

$$
\begin{array}{ll}
1 & =\text { Sangat Setuju } \\
2 & =\text { Setuju } \\
3 & =\text { Tidak Setuju }
\end{array}
$$

Dari tabel pengujian pengguna diatas dapat disimpulkan bahwa pembuatan aplikasi prediksi penjualan di cv diato wood sejahtera berbasis web mendapat tanggapan yang baik dari penguna, ini membuktikan bahwa aplikasi ini sudah berjalan dengan baik dan semestinya 


\section{KESIMPULAN DAN SARAN}

\subsection{Kesimpulan}

Berdasarkan beberapa pengujian yang telah dilakukan didapatkan kesimpulan :

4. Hasil pengujian fungsional menunjukkan hasil $100 \%$, artinya semua fitur program dapat berjalan sesuai dengan fungsinya.

5. Hasil pengujian aplikasi peramalan menggunakan metode trend moment dapat dipergunakan untuk meramalkan jumlah penjuala kayu lapis di cv diato wood sejahtera yang akan datang

6. Sistem aplikasi ini mengunakan sampel data real dari data penjualan kayu lapis di $\mathrm{cv}$ diato wood sejahtera 2 tahun kebelakang yaitu tahun 2017 dan tahun 2018 sebagi nilai perbandingan

7. Aplikasi prediksi penjualan di cv diato wood sejahtera berbasis web mendapat tanggapan yang baik dari penguna, ini membuktikan bahwa aplikasi ini sudah berjalan dengan baik dan semestinya

\subsection{Saran}

Berdasarkan penelitian yang telah dilakukan, maka penulis dapat memberikan saran-saran untuk pengembangan selanjutnya antar lain :

1. Aplikasi prediksi penjualan kayu lapis di $\mathrm{cv}$ diato wood sejahtera dapat dilengkapi dengan perhitungan prediksi penjualan dengan menggunakan metode metode lain ataupun Bahasa pemograman lain

2. Aplikasi prediksi penjualan kayu lapis ini mengunakan barang di cv diato wood sejahtera yang masih sedikit, kedepannya dapat dikembangkan dengan menambah barang lainnya

\section{DAFTAR PUSTAKA}

[1] B.Sakur, Stendy. 2010. PHP 5 Pemrograman Berorientasi Objek-Konsep dan Implementasi. Yogyakarta : Andi.

[2] Kusumadewi, Sri, Haryati, Sri, Harjoko, Agus, Wardoyo, Retantyo.2006.Fuzzy
[3] Amijaya, D .T. 2013. Teknik Proyeksi Bisnis. Universitas Winaya Mukti. (Online), tersedia: http://fudinzainal.com.

[4] Subagyo, P. 1986. Forecasting Konsep dan Aplikasi, BPFE Yogyakarta: Yogyakarta.

[5] Sugiarto, dan Dergibson, S. 2002. Metode Statistika Untuk Bisnis dan Ekonomi. Jakarta : PT.Gramedia Pustaka Utama. Halaman 208217.

[6] Astuti. 2014. Batik Sistem Perencanaan Penjualan Pada Fachi Collection Dengan Metode Trend Moment. Jurnal Ilmiah, (Online), tersedia: http://repositori.amikomj.ac.id, 21

[7] Soepeno, B. 2012. Modul Peramalan Penjualan. Malang: Politeknik Negeri Malang, (Online), tersedia: http://www.pro.edukasi.com, diunduh 15 November 2014.

[8] Soebandhi, A.S.S. Modul 8 Analisa Trend dan Forecasting. (Online), tersedia: http://www.idiedownload.com, diunduh 15 November 2014.

[9] Widodo. 2008. Peramalan Penjualan Sepeda Motor Honda pada CV.Roda Mitra Lestari. Jakarta : Universitas Guna Darma. (Online), tersedia: http://gunadarma.ac.id, diunduh 01 Desember 2014.

[10] Muthia. 2013. Penerapan Metode Trend Moment dalam Forecast Penjualan Motor Yamaha di PT. Hasjrat Abad. Jurnal Ilmiah, (Online), tersedia : http://kim.ung.ac.id, diunduh 20 November 2014.

[11] Peranginangin, Kasiman. 2006. Aplikasi Web dengan PHP dan MySQL. Yogyakarta: ANDI Yogyakarta.

[12] Proboyekti, U. 2008. Flowchart. (Online), tersedia: http://lecturer.ukdw.ac.id, Diunduh tanggal 12 Desember 2014. 